\title{
The Role of Informal Labour Market Conditions and Transferrable Competences on Informal Employments for Secondary School Graduates in Kigoma District, Tanzania
}

\author{
Adam Mnyavanu $^{1 *}$ Sotco C. Komba ${ }^{2} \quad$ John V. Msinde ${ }^{3}$ \\ 1.Agency for the Development of Education Management. P. O. Box 71 Bagamoyo, Tanzania \\ 2.College of Social Sciences and Humanities, Sokoine University of Agriculture, P. O. Box 3035, Morogoro, \\ Tanzania \\ 3.Tanzania Institute of Accountancy, P. O. Box 35176, Dar es Salaam, Tanzania
}

\begin{abstract}
Secondary school graduate output in Tanzania has enormously increased without a proper placement plan in the labour market. Specifically, the paper delineates the differences in informal labour market conditions and transferrable competences between urban and rural secondary school graduates; presents an examination of informal employments for secondary school graduates; and denotes the impact of transferrable competences and informal labour market conditions on secondary school graduates' informal employment. A cross-sectional study design was employed to collect quantitative and qualitative data. Descriptive results showed trading, fishing, transportation, mechanics, food vending, palm oil processing and farming to be among main informal employments in which secondary school graduates are engaged. Mann-Whitney $U$ test showed that there were significant differences in the effect of explanatory variables between urban and rural secondary school graduates. Binary Logistic Regression analysis showed that 8 variables namely, informal labour market accessibility, financial capital, social networks, labour market legal framework, self-efficacy, interpersonal relation, entrepreneurship, and farming competences had significant influence on informal employments of secondary school graduates. The results from focus group discussions and key informant interviews were consistent with the findings from the quantitative data. It is thus concluded that informal labour market conditions and transferable competences have an influence on informal employment of secondary school graduates. Therefore, adjustments of informal labour market conditions and transferable competences could be an effective tool of expanding informal employments for secondary school graduates in the informal labour market. The findings emphasise on the need for alerting Local Government Authorities, labour offices, employment agencies, and Non-Governmental Organisations to adjust and re-organize informal labour market conditions and improve transferable competences for secondary school graduates, and hence, improve chances for the graduates getting informal employment.

Keywords: Informal labour market conditions, transferable competences, informal employment, secondary school graduates.
\end{abstract}

DOI: $10.7176 / \mathrm{EJBM} / 13-2-05$

Publication date: January $31^{\text {st }} 2021$

\section{Introduction}

Informal employments, despite many challenges against them, offer chances for work to millions of employment seekers from all lifestyles around the world; the educated and uneducated, young and old, rich and poor, and people with special needs get such employments. According to ILO (2019), the informal employment market constitutes a larger share of total employments in the developing and emerging countries with $73 \%$ of all non-agricultural employments in developing and 59\% in emerging economies. Natarajan et al. (2020) show that expansion of informal economy expands the size of informal employments and that $93 \%$ of all informal employments are in informal sector. The definition of Informal employment adopted in this study is consistent with the clarification of International Conference of Labour Statistician (ICLS) ILO (2003). Informal employment is defined as any kind of unregulated employment which is not subject to income taxation, national labour legislation, and social protection benefits such as severance pay, advance notice of dismissal, and paid annual or sick leave. Informal employments are all informal jobs carried out in the informal sector enterprises, formal and households during a given reference period (ILO, 2003). The informal employments involve; employers and employees working in their own enterprises, contributing family workers, informal cooperative producers, informal paid domestic workers, and goods and service producers for own house use

The trend in Africa is not different as informal employment constitutes 78 percent of all employments (Verick, 2017) and 66 percent of all employments are in the informal sector (ILO, 2013). This reality is supported by IMF (2016) which shows that, the expansion in informal employments in Sub-Saharan Africa is a result of growing informal sector and transformation in the growing formal production systems. A study by Stuart et al. (2018) show that 7 in 10 nonfarm workers in Sub-Saharan Africa are in informal employment. Kucera et al. (2019) shows that there is a dualism of good and bad employment in informal employment in the developing and emerging 
economies like Africa and Latin America. That dualism is found also in formal employment (ILO, 2019; Natarajan et al., 2020).

In Tanzania, the Integrated Labour Force Survey report (ILFS) URT (2014) shows that 75.9 percent or three quarter of all paid non-agricultural employments are informal employments. In addition, a report by Danish Trade Union Development Agency DTDA (2018) in Tanzania shows that, when agricultural activities are included, the informal employments account for 85 percent for Tanzania Mainland and 88 percent for Zanzibar. The ILFS report URT (2014) shows that secondary school graduates are among of the growing group in the informal labour market. The ILF report correspond with ordinary level secondary examinations result reports (URT, 2008, 2017a, 2018, 2020). The reports show that Secondary school graduates entry in the labour market increases yearly whereby from 2008 to 2019 secondary education examinations; only $21.5 \%$ scored good results and the rest $78.5 \%$ scored bad. Overall, the data show that one-third $(30.5 \%)$ of all secondary school graduates during the period mentioned were a complete failure. Those with bad results had no prospects of continuing with further education in a normal path but continuing with other life in the labour market most likely informal employments.

On the other hand, while secondary school graduates increase in the job market, yet they comprise the highest unemployed group in terms of unemployment based on education categories. The URT (2014) shows that 13.8 percent of the unemployed workforce are secondary school graduates. It is argued by Haji (2015) and IDRC (2016) that, majority of youth in Tanzania are trapped in informal and unskilled jobs. A study by Haji (2015) shows that, of the approximately 900000 youths who entered the labour market in Tanzania in 2011/12, 14 percent did not complete primary education, 44 percent did not transit to secondary education, and only 4 percent of those who joined secondary education had transited beyond O-level. Furthermore a report by DTDA (2018) shows that of the 850000 young entrants in the labour market annually only 50,000 to 60000 of them get a formal employment and the remaining are either in informal employments or are unemployed. Studies by Tan (2016) and Suleiman et al.(2018) show that youth unemployment yearly increases following secondary education expansion but that there are fewer or no places to work in the formal employment. While they face unprecedented fewer employment opportunities at the same time are unskilled or inadequate competent $(\mathrm{H}$. Tan, 2016). This imply that majority of the secondary school graduate entrants in the labour market are likely ending in the informal employment. it is at this juncture the informal employment needs a positive reinforcement despite its many challenges because it is a bigger source of employment. The data tells the necessity and vastness of informal employment but not well studied. To help increase employment and reduce unemployed for secondary school graduates, the paper aims to understand the influence of informal labour market conditions and transferable competences on informal employment.

Reviewed Tanzania related literature on informal sector and informal employment, for example Tulia (2010), Razmara et al.(2013) and Ellis et al. (2017), focused on different bottlenecks in the informal employment, e.g. precarious working environment, and lack of job security. Nevertheless, the studies did not focus on secondary school graduates in particular taking into consideration their size in the labour market and being the highest unemployed group among different education categories. In addition, despite their contributions referred studies did not look critically at the prevailing informal labour market conditions and the impact of transferable competences on informal employments.

Examination of informal labour market conditions and transferable competences is enabled by two theories from informal employment studies: Neoliberalism theory (Peters, 2019) and Human Capital Theory (Berntson et al., 2016). The neoliberalism theory focus on the reduction of cumbersome regulations, taxes and government interference in the labour market which will encourage start-ups and increase employments. While the human capital theory focus on the individual possessions particulary competences as a capital for employent acqusition. The study assumptions are; if the labour market conditions are well adjusted and accompanied by competent employement seekers then there is a possibility of increasing employements fro secondary school graduates particulary informal employements which has a chance to absord majority of them.

\section{Neoliberalism theory}

The neoliberalism theory, advocated by Hayek, Popper and Friedman under famously known Austrian and Chicago neoliberalism schools (Peters, 2019). The neoliberalism theory explains that both the labour market and individuals in the labour market need autonomy to boost production and employment expansion (Williams, 2014). The neoliberalism theory in the labour market believes in labour accessibility, deregulation, free flow of financial capital, interaction of enterprises and which in turn encourages innovations and expansion of formal and informal employment opportunities (Huang, et al., 2020). The theory sees informal employment as an alternative approach to resolving unemployment and revive stagnant economic growth to expand employment both formal and informal (Williams, 2013). Informal labour market conditions which determine entry in the informal employments include informal labour market accessibility, informal labour work quality, financial capital, social networks, and labour market legal framework (ILO 2004; 2013; and Chen, 2012). Overall, based on Neoliberalism and basic ILO definitions, this paper operationally defines informal labour market conditions to include informal labour market 
accessibility, informal labour work quality, financial capital, social networks, and labour market legal framework. Hypothesis 1: The informal labour market conditions indicated by access, quality, financial capital, social network and labour market legal aspects have no statistical significant influence on informal employment for secondary school graduates.

\section{Human capital theory}

The The HCT embraces the competences and skills as fundamental employment ingredients (Nafukho et al., 2004; Tan, 2014; Berntson et al., 2016). It establishes a link between education level and occupational choices. The theory underscores the importance of developing young generation to fit for current and future need of work force. In the context of this study, theory has aided in evaluating the relationship between transferable comptences and employment outcome for secondary school graduates. While operationalisation of transferable competences in this paper is based on Akhter et al. (2012); Munby et al. (2009); Kim and Lee (2018) works which identified self-efficacy, meta-cognition, interpersonal relations, entrepreneurship as constituents of transferable competences. Additionally, from experience of local environment in the study area farming is added as it comprises bigger part of informal employments in Tanzania (URT, 2014). Transferable competences are synonymously termed as noncognitive competences, practical skills, soft skills, soft outcomes, and life skills (Blades et al. 2012).

Hypothesis 2: The transferrable competences indicated by self-efficacy, metacognition, interpersonal relationship, entrepreneurship and farming have no statistical significant influence on informal employment for secondary school graduates.

\section{Rural-urban disparity in informal employment choices}

The dichotomy of informal employment between rural and urban areas is well documented by Gupta (1993) and Chaudhuri (2017) that there are more chances in urban centres with blend of choices compared to rural areas. Therefore, it is worth studying whether there are any differences and of what sizes for informal labour market conditions and transferable competences between rural and urban secondary school graduates. This is done to have a profound understanding of the informal employment rural areas separately formal urban areas so that appropriate recommendations can be put. It is thus hypothesised that.

Hypothesis 3: There is no difference in informal labour market conditions and transferrable competences between urban and rural respondents.

\section{METHODOLOGY}

\subsection{Study Area and Sampling}

The study was conducted in Kigoma District which has both rural and urban settings. The District was chosen because of its poor socio-economic development and unemployment. Kigoma region ranks low in a number of social economic indicators such as households poverty and per capita income (URT, 2016; 2017). In addition, Kigoma Region and Kigoma District in particular is among of the areas with surplus labour and low rate of employment, with a yearly increase of unemployment (URT, 2019). The ILO (2013) shows that there is a relationship between employment accessibility and reduction of poverty and increase of income. Therefore, is worth studying variables with influence of rising informal employments to serve majority of unemployed secondary school graduates.

The study area was stratified into urban and rural areas. Two divisions (Kigoma Kaskazini from urban areas and Mahembe) from rural areas were randomly selected. Two wards from each division, two hamlets from each urban ward, and two villages from each rural ward were randomly selected. The study population encompassed secondary school graduates who had completed secondary school education from 2008 to 2018 from the two divisions. In each division, two wards were randomly selected: Mwanga and Kibirizi from urban areas, and Bitale and Mahembe from rural areas. Furthermore, four hamlets from the urban division (Mlole, Nazareti, Kibirizi, and Bushabani) and four villages from the rural division (Bitale, Bubango, Mahembe, and Chankabwimba) were randomly selected. The unit of analysis was an individual secondary school graduate living in the selected areas. Village and Hamlet Chairpersons assisted the researcher in identifying households with members who had graduated within the specified period. A combination of snowball and random sampling were used. The population of secondary school graduates between 2008 and 2018 were 2197. Yamane (1973 cited in Israel, 2012), provides a simplified formula to calculate sample sizes with a 95percent confidence level and $\mathrm{p}=0.05$.

$$
n=\frac{N}{1+N(e)^{2}}
$$

Where $\mathrm{n}=338$ was as the sample size, $\mathrm{N}=2197$ was the population size, and $\mathrm{e}=0.05$ was the level of precision. The sample size ratio for each village or hamlet was calculated using a proportional allocation formula method whereby $\mathrm{q}=$ number of respondents from each village/hamlet.

$q=\frac{n}{N} * n$ 
Table 1: Number of sampled households in each village/ hamlet

\begin{tabular}{lccccccccc}
\hline Area & \multicolumn{4}{c}{ Urban } & \multicolumn{5}{c}{ Rural } \\
Division & \multicolumn{3}{c}{ Kigoma Kaskazini } & \multicolumn{4}{c}{ Mahembe } \\
\hline Ward & \multicolumn{2}{c}{ Mwanga } & \multicolumn{2}{c}{ Kibirizi } & \multicolumn{3}{c}{ Bitale } & \multicolumn{3}{c}{ Mahembe } \\
Hamlet/Villa & Mlol & Nazaret & Kibiriz & Bushaba & Bital & Bubang & Mahemb & Chankabwim & Tota \\
ge & $\mathrm{e}$ & $\mathrm{i}$ & $\mathrm{i}$ & $\mathrm{ni}$ & $\mathrm{e}$ & $\mathrm{o}$ & $\mathrm{e}$ & ba & 1 \\
$\mathrm{~N}$ & 420 & 341 & 391 & 293 & 242 & 191 & 184 & 135 & 219 \\
$\mathrm{q}$ & 65 & 53 & 60 & 45 & 37 & 29 & 28 & 21 & 338 \\
\hline
\end{tabular}

In addition, eight Key Informants (KIs) interviews were conducted. The key informants (KIs) were Education Official in the Ministry of Education Basic Education Directorate and Directorate of Curriculum Development at Tanzania Institute of Education. Others were: Tanzania Employers Association Chairperson Representative, an Education Expert at TWAWEZA, owner of palm oil processing machines at SIDO in Kigoma and the Chief Education Quality Assurer of Kigoma District. Also, Kigoma District Community Development Officer and Labour Officer were key informants. KIs were selected based on their expertise in key study themes so that they could provide in-depth understanding of the secondary education, labour market and employment sectors. Moreover, four Focus Group Discussions (FGDs) were conducted; Each FGD involved six to nine participants. The FGD were conducted at Mlole, Kibirizi, Mahembe and SIDO in Kigoma. Participant selection criteria for participants were based on being secondary school graduates who graduated between 2008 and 2017 except for Mlole which involved secondary school teachers from Mlole secondary school.

The study employed a cross-sectional research design which enabled collection of data to be taken at a single point in time as suggested by Sedgwick (2014). On the other hand, the design provides a chance for combining qualitative and quantitative data collection methods. The combination of data collection methods offered a chance of obtaining triangulated information.

\subsection{Data Collection}

The study used both quantitative and qualitative methods to collect primary data. Quantitative data were collected using a structured questionnaire. The questionnaire was used to collect data on respondents' socio-demographic data, transferable competences, perceptions on informal labour market conditions, and their employment or unemployment status. Qualitative data were collected through Focus Group Discussions (FGDs) and Key Informant Interviews (KIIs). Females and males were separated during FGD discussions. The qualitative data were meant to increase understanding on informal employment and the way it was affected by informal labour market conditions and transferable competences among secondary school graduates.

\subsection{Measurements of Variables}

\subsubsection{Explanatory variables}

The explanatory variables in this paper include informal labour market conditions and transferrable competences. Informal labour market conditions were informal labour market accessibility, informal labour work quality, financial capital, social networks, and labour market legal framework. Transferrable competences were selfefficacy, meta-cognition, interpersonal relationship, entrepreneurship, and farming competences. The aforementioned variables were measured using a summative Likert scale to which there were five alternative responses $(1=$ strongly disagree, $2=$ disagree, $3=$ neutral, $4=$ agree and $5=$ strongly agree $)$. Scores on the variables were summed up to called up the levels of measurement of the variables from nominal to ordinal and continuous levels. Furthermore, control variables used were places of living (categorical, $0=$ rural; $1=$ urban), age (continuous), and marital status (categorical, $0=$ not married, $1=$ married).

\subsubsection{Outcome variable}

The outcome variable was modelled as a binary variable in terms of employment $=1$ or otherwise $=0$. By being employed, a respondent was expected to be working in any of the following sectors: fish industry, forestry, building construction, being a local broker, trading, cleaning, carpentry, shoe shining, accommodation, mechanics, transportation, food vending, street vending, agriculture, electrical, household activities, hairdressing, port and marine, bartending, and palm processing.

\subsection{Model fit specification and diagnosis}

To ascertain on proper specification of the model, multicollinearity, serial dependence, Kaiser-Meyer-Olkin measure of sampling adequacy (KMO) and Bartlett's strength test of variable relationship or Sphericity were performed. To test the assumptions, it is recommended firstly to satisfy that the chosen model is robust enough and that the assumptions are not violated (Bartlett, 1954; Kaiser, 1970; and Field, 2009). Multicollinearity shows Variance Inflation Factor (VIFs) <3, which were within the acceptable range of being less than 10 (Field, 2009). 
The serial dependence test shows 1.96 (appro. 2) Durbin-Watson which shows absence of serial dependence of residuals, whereby Field (2009) recommends 2 . In addition, a KMO value of $\leq 0.794$ and a Bartlett's Test value of 0.000 with a positive definite matrix of good data were used. Field (2009) recommends a KMO value of between 0.5 and 1 for the adequacy of sampling and a Bartlett's significant value of $<0.05$ for no identity matrix data. The assumptions were met for all the scales.

\subsection{Data Analysis}

SPSS software version 20 was used for statistical analysis. The analysis involved descriptive and inferential statistics. Inferential analysis included Mann-Whitney U test and binary logistic regression model. Binary logistic regression model is shown in equation (i).

$\log \left(\mathrm{P}_{\mathrm{i}} / 1-\mathrm{P}_{\mathrm{i}}\right)=\beta_{0}+\beta_{1} \mathrm{X}_{1}+\beta_{2} \mathrm{X}_{2}+\ldots+\beta_{15} \mathrm{X}_{15}+\mathrm{e} \ldots \ldots \ldots \ldots \ldots \ldots \ldots \ldots \ldots \ldots$. Equation (i)

Where: $\log \left(\mathrm{P}_{\mathrm{i}} / 1-\mathrm{P}_{\mathrm{i}}\right)=$ is the natural logarithm of the status of informal employment for a respondent if he/she is employed or not employed. $\mathrm{Pi}=$ probability of a respondent being employed; $1-\mathrm{P}_{\mathrm{i}}=$ probability of respondent being not employed and $\beta_{0}=$ Constant (Y- interception).

$\beta_{1}-\beta_{12}=$ Logarithm of regression coefficient of explanatory variables. These variables include informal labour market conditions, and transferrable competences as presented in the measurement of variables. Additionally, qualitative data were analysed through content analysis, coupled with discourse analysis. Content analysis highlighted the main themes which emerged from key informant interviews and FGDs while discourse assisted in separating the ideas in relation to identities and position of the source of the information for a meaningful understanding of the findings.

\section{RESULTS AND DISCUSSION}

The results section presents findings, analysis, and discussions on the four specific objectives of this paper. These include identifying informal employment for secondary school graduates based on places of living, examining differences in transferrable competences and informal labour market conditions between urban and rural secondary school graduates, and determining the impact of transferrable competences and informal labour market conditions on employment status of secondary school graduates, that is, employed or not employed.

\subsection{Informal Employment for Secondary School Graduates}

The informal employments identified were analysed using multiple response analysis. The results presented in Table 2 show responses based on the place of living of the respondent. The findings show that twenty informal employment areas were mentioned with a total of 279 choices for urban dwellers and 128 choices for rural dwellers were mentioned. The findings show that the leading choices for urban areas were agriculture $38.2 \%$, fish industry $27.6 \%$, palm processing $20.3 \%$, trading $17.9 \%$, transportation $16.3 \%$, food vending $14.6 \%$, accommodation $12.2 \%$, hairdresser $11.4 \%$, bartender $10.6 \%$, building construction $9.8 \%$, mechanics $8.9 \%$

The findings in Table 2 indicate differences in terms of informal employment choices between urban and rural respondents; both categories showed involvement in a number of same informal employments but with differences in preferences. For instance, trading was ranked higher in urban areas compared to the rural areas. The findings provide a trend on the way agriculture, fish industry, palm oil processing and trading activities are distributed between urban and rural secondary school graduates. In addition, the findings show that trading absorbed many secondary school graduates entering the informal employment market in urban areas. The findings imply that building simple skills related to trading is likely to assist many secondary school graduates entering the informal labour market. Furthermore, the findings suggest that the on-going expansion of urban areas and migration of youths into these areas makes agriculture, fish industry, palm oil processing and trading likely options for them as a livelihood strategies. Similar findings are reported in a studies by Amphune (2012) and Stokes (2017) who suggested that trading was among the short-term coping mechanisms among the youth migrating to the urban centres, and when financial capital vulnerability is managed, business becomes a long term survival strategy. 
Table 2: Informal employments for secondary school graduates

\begin{tabular}{|c|c|c|c|c|c|c|}
\hline informal employments & \multicolumn{2}{|c|}{ Urban } & \multicolumn{2}{|c|}{ Rural } & \multicolumn{2}{|c|}{ Total } \\
\hline & Frequency & Percent & Frequency & Percent & Frequency & Percent \\
\hline Forestry & 4 & 3.25 & 3 & 2.439 & 7 & 5.7 \\
\hline Building Construction & 9 & 7.32 & 3 & 2.439 & 12 & 9.8 \\
\hline Local brokers & 4 & 3.25 & 0 & 0.000 & 4 & 3.3 \\
\hline Trading & 13 & 10.57 & 9 & 7.317 & 22 & 17.9 \\
\hline Cleaners & 10 & 8.13 & 0 & 0.000 & 10 & 8.1 \\
\hline Carpentry & 8 & 6.50 & 1 & 0.813 & 9 & 7.3 \\
\hline Shoe shining & 3 & 2.44 & 1 & 0.813 & 4 & 3.3 \\
\hline Fish industry & 27 & 21.95 & 7 & 5.691 & 34 & 27.6 \\
\hline Accommodation & 13 & 10.57 & 2 & 1.626 & 15 & 12.2 \\
\hline Mechanics & 9 & 7.32 & 2 & 1.626 & 11 & 8.9 \\
\hline Transportation & 15 & 12.20 & 5 & 4.065 & 20 & 16.3 \\
\hline Food vending & 12 & 9.76 & 6 & 4.878 & 18 & 14.6 \\
\hline Street vender & 8 & 6.50 & 2 & 1.626 & 10 & 8.1 \\
\hline Agriculture & 9 & 7.32 & 38 & 30.894 & 47 & 38.2 \\
\hline Electrical & 6 & 4.88 & 0 & 0.000 & 6 & 4.9 \\
\hline Household activities & 7 & 5.69 & 1 & 0.813 & 8 & 6.5 \\
\hline Hairdresser & 10 & 8.13 & 4 & 3.252 & 14 & 11.4 \\
\hline Port and Marine & 4 & 3.25 & 1 & 0.813 & 5 & 4.1 \\
\hline Bartender & 11 & 8.94 & 2 & 1.626 & 13 & 10.6 \\
\hline Palm processing & 19 & 15.45 & 6 & 4.878 & 25 & 20.3 \\
\hline Total responses & 279 & 226.8293 & 128 & 104.065 & 407 & 330.9 \\
\hline Total & 79 & 64.22764 & 44 & 35.772 & 123 & 100 \\
\hline
\end{tabular}

In addition, the findings showed that agriculture was ranked high in the rural areas, which is a common phenomenon. However, the findings showed that there were respondents dealing with agriculture in urban areas as well, implying that urban and peri-urban agriculture is a source of employment to secondary school graduates and can further be developed to accommodate many of them. Further findings from a key informant in the district, Chief Education Quality Assurance Officer, with regard to increasing participation in agriculture are shown by the following quote:

“... I see many youths are now undertaking vegetable farming in open spaces in our towns, especially in areas with water sources... that is a good thing,.. Secondary schools can opt for training students on simple farming practices so that when they complete schools, they can easily get something to do in farming...(KI, $6^{\text {th }}$ June 2019$)$.

The KI shows the way secondary school graduates get informal employment in urban farming for income generation. This informs on the importance of farming competences which can assist them produce more to meet demands for food in urban. Informal employment in farming is potential and likely to provide employment for majority of secondary school graduates. The finding on farming correspond with argument by Game and Primus, (2015) that growth of urban agriculture is on the rise as shown by as part of sustaining food security and employment. Also, a study by Hardman and Larkham, (2014) showed that urban agriculture is gaining attention and becoming more organised in terms of policies. From the policy perspective this trend of youth increasing employment in agriculture entails a much broader look on future prospects for consideration in terms of broadening opportunities for employment of secondary school graduates in agriculture as a key informal sector.

Furthermore, the findings showed that fishing and fish business were the third most reported activities in the multiple responses analysis for urban respondents and a fourth for rural respondents. Studies by Mkama, et. al.(2011) and URT (2016) showed fishing and related businesses as a source of informal employment but was at artisanal level with crude fishing facilities and technologies.

Similarly, palm oil processing, transportation, food vending, mechanics and hairdressing were among the notable informal employments secondary school graduates were involved with in Kigoma District, but with variations among urban and rural respondents. Generally, the findings show that urban respondents had more choices of informal employments and possibilities of doing a variety of informal employments compared to rural respondents.

Furthermore, two theoretical implications are drawn; one is on the plurality of occupations for secondary school graduates in the informal employment and secondly, kinds of skills needed to fit in the specified employments. On the first implication, the neoliberalism theory is consistent with the findings, based on plurality 
and dispersion of the occupation. Secondly, on kinds of competences required, the neoliberalism and human capital theory has a guide on how better transferable competences can be provided for secondary school graduates to fit in their informal employments. Silva (2013) shows that cognitive and non-cognitive competences can be combined and provided in primary and secondary education to prepare school leavers of this level for employment or on transit to tertiary and higher education.

Consequently, these findings have informed on informal employments with high catchment for secondary school graduates. The findings on multiplicity of informal employment for secondary school graduates in Table 2 correspond with the neoliberalism theory and rises implications for human capital theory. After completion of secondary education, they pursue different areas of informal employment to earn living. Implications for the human capital theory are on competences and prior learning they got from secondary school during their studies whether it was relevant connection with their current informal employment engagement.

\subsection{Differences in Informal Labour Market Conditions and Transferrable Competences Between Urban and Rural Secondary School Graduates}

Informal labour market conditions and transferrable competences and were tested to find how they were distributed among Urban and rural Secondary school graduates. The findings in Table 3 present Mann-Whitney U test differences for transferrable competences and informal labour conditions between urban and rural secondary school graduates. The findings show that seven out of 10 variables tested indicated significant differences and hence the rejection the null hypothesis that the variables had the same influence on urban and rural respondents. The results show that informal labour market accessibility for the urban Median $(\mathrm{Mdn})=24$ differed signficantly from that for the rural median $(M d n=16),(p=0.007)$, Mann-Whitney test $(U)=12519.000, z=-11.358, r=$ 0.618. Social networks for urban secondary school graduates $(\mathrm{Mdn}=28)$ differed signficantly from that for rural areas $(\mathrm{Mdn}=23),(\mathrm{p}=0.025) \mathrm{U}=11846.000, \mathrm{z}=-7.152, \mathrm{r}=-0.389$. Additionally, informal labour market legal framework for urban secondary school graduates $(\mathrm{Mdn}=18)$ differed signficantly from that for unemployed secondary school graduates $(\mathrm{Mdn}=16), \mathrm{p}=0.015, \mathrm{U}=10771.500, \mathrm{z}=-5.431, \mathrm{r}=-0.2954148$. Furthermore, SelfEfficacy for urban $(\mathrm{Mdn}=18)$ differed significantly $(\mathrm{p}=0.018)$ from that for rural secondary school graduates $(\mathrm{Mdn}=15), \mathrm{U}=10809.000, \mathrm{z}=-2.375, \mathrm{r}=-0.129$. Interpersonal relationship for urban $(\mathrm{Mdn}=19)$ differed significantly $(\mathrm{p}=0.041)$ from that for rural secondary school graduates $(M d n=15), U=12649.500, z=-6.204, r$ $=-0.3374363$. Entrepreneurship for urban $-(\mathrm{Mdn}=20)$ differed significantly $(\mathrm{p}=0.041)$ from that for rural secondary school graduates $(\mathrm{Mdn}=17), \mathrm{U}=12770.500, \mathrm{z}=-5.061, \mathrm{r}=-0.2752922$. Lastly, farming for urban secondary school graduates $(\mathrm{Mdn}=18)$ differed significantly $(\mathrm{p}=0.041)$ from that for rural $(\mathrm{Mdn}=22), \mathrm{U}=$ $12770.500, \mathrm{z}=-5.061, \mathrm{r}=-0.2752922$

In determining the value of the effect size, Field (2009) argues that effect size provides the position of the effect a variable has with a range of no effect (0.000) to perfect effect (1). The result interpretation is that $\mathrm{r}=0.1$, is a small effect; $r=0.3$ is a medium effect; and $r>0.3$ is a large effect. The results show that the effect sizes for informal labour market accessibility, financial capital and social networks were large whereas legal aspects indicated a medium effect size. The remaining variables, particularly informal labour market legal framework, interpersonal relationship, and farming indicated a medium effect size; and lastly, self-efficacy showed a small effect size. The effect size provides informal labour market conditions with large effect size whereby interventions can be considered.

Further, median scores of the significant variables were larger on the side of the urban respondents except in farming for which the score was lager in rural areas, indicating that the variables had some effect on their informal employment choices. On the other hand, farming had a higher median score among rural respondents compared to urban respondents. This means farming had more effect on their informal employment choices compared to urban respondents. 
Table 3: Differences in transferrable competences and informal labour market conditions between urban and rural secondary school graduates

\begin{tabular}{|c|c|c|c|c|c|c|c|}
\hline Explanatory variables & $\begin{array}{l}\text { Place of } \\
\text { Living }\end{array}$ & $\mathbf{N}$ & Median & Mann-Whitney U & $\mathbf{Z}$ & Sig. & $\mathbf{r}$ \\
\hline \multirow{2}{*}{$\begin{array}{l}\text { Informal Labour Market } \\
\text { Accessibility }\end{array}$} & Urban & 223 & 24 & 12519.000 & -11.358 & 0.007 & -0.6177962 \\
\hline & Rural & 115 & 16 & & & & \\
\hline \multirow[t]{2}{*}{$\begin{array}{l}\text { Informal } \\
\text { Quality }\end{array}$} & Urban & 223 & 16 & 12701.000 & -.144 & 0.885 & -0.0078538 \\
\hline & Rural & 115 & 16 & & & & \\
\hline \multirow[t]{2}{*}{ Financial Capital } & Urban & 223 & 25 & 12678.500 & -8.170 & 0.019 & -0.444389 \\
\hline & Rural & 115 & 20 & & & & \\
\hline \multirow[t]{2}{*}{ Social networks } & Urban & 223 & 28 & 11846.000 & -7.152 & 0.025 & -0.3890118 \\
\hline & Rural & 115 & 23 & & & & \\
\hline \multirow[t]{2}{*}{$\begin{array}{l}\text { Informal labour market } \\
\text { legal framework }\end{array}$} & Urban & 223 & 18 & 10771.500 & -5.431 & 0.015 & -0.2954148 \\
\hline & Rural & 115 & 16 & & & & \\
\hline \multirow[t]{2}{*}{ Self-Efficacy } & Urban & 223 & 18 & 10809.000 & -2.375 & 0.018 & -0.1292045 \\
\hline & Rural & 115 & 15 & & & & \\
\hline \multirow[t]{2}{*}{ Metacognition } & Urban & 223 & 16 & 11787.000 & -1.219 & 0.223 & -0.0663006 \\
\hline & Rural & 115 & 15 & & & & \\
\hline \multirow[t]{2}{*}{ Interpersonal Relationship } & Urban & 223 & 19 & 12649.500 & -6.204 & 0.041 & -0.3374363 \\
\hline & Rural & 115 & 15 & & & & \\
\hline \multirow[t]{2}{*}{ Entrepreneurship } & Urban & 223 & 20 & 12770.500 & -5.061 & 0.030 & -0.2752922 \\
\hline & Rural & 115 & 17 & & & & \\
\hline \multirow[t]{2}{*}{ Farming Competences } & Urban & 223 & 18 & 12688.000 & -7.158 & 0.009 & -0.3893618 \\
\hline & Rural & 115 & 22 & & & & \\
\hline
\end{tabular}

Considering Mann-Whitney $U$ test, the findings in Table 3 show that there were significant differences in the ways urban and rural respondents were affected by informal labour market conditions and transferable competences. The informal labour market accessibility corresponding effect size ( $r$ ) of 0.6 that was above edge suggests the highest consideration among other variables. In addition, the findings show that financial capital had a strong size effect and was more preferred by urban respondents than rural respondents. The findings correspond with the findings in Table 2, whereby non-farm activities such as trading had much participation among urban graduates suggesting higher demand for financial capital to run these activities. In addition, farming showed higher effect for rural respondents which suggests that it needs higher deliberations for rural respondents compared to other informal labour market conditions for rural areas. Improvement of farming in terms of support for farm implements, skills, and technologies is likely to increase employment opportunities.

Overall, the findings in Table 3 affirm the neoliberalism theoretical stand for plurality of activities and differences in informal employment choices. The rural-urban disparity and the multiplicity of activities, as seen in Table 2, show the ways these secondary school graduates hustle differently in the informal labour market. The theory contends imposition of systematic social general goals for people. The goals could be national development plans, education and skill provisions for students and employment seekers and investment. The theoretical inferences and the findings suggest policy implications in relation to informal employments for the studied group. First, any intervention strategy to improve employment conditions should take into consideration the subject being affected, that is a combination of bottom-up and top-down approaches as is also suggested by Gao (2016) and Isidiho (2016). Secondly, the findings and the theoretical base of the study suggest redesigning of skills content and delivery for secondary school graduates. A tailor-made content is likely to fit more than a predetermined content. Lastly, the findings and the theory raise questions on the relevance of secondary education for the majority who do not proceed for higher education and whether students in schools are learning what is really needed in working places.

\subsection{Impact Informal Labour Market Conditions on Secondary School Graduates' Employment Status}

Binary logistic regression was employed to determine effect of informal labour market conditions on employment status. The model summary showed an R Square of 0.645 , suggesting that the model explained $64.5 \%$ of the variations in the outcome variable as explained in the specified explanatory variables. The results of regression analysis are displayed in Table 4 and show that four out of five informal labour market conditions variables were significant.

Informal labour market accessibility was positive and significant at $p=0.001$ indicating a strong positive influence on employment. This indicates that an increase in informal labour market accessibility increases the odds 
of getting informal employment. From the findings, various lessons can be learnt; one is the need of opening up of more opportunities for informal labour market accessibility in rural areas by increasing social services such as electricity, which in turn would pave a way for small-scale industries, and in turn providing employment opportunities for rural secondary school graduates in Kigoma District. Secondly, the findings show the huge role played by the informal labour market, which absorbs the majority of secondary school graduates; hence, there is a need of improving the sector. Therefore, the importance of informal labour market accessibility in terms of increasing employment opportunities cannot be overemphasised as the findings indicate.

Another noteworthy variable with strong influence on employment was financial capital. The findings showed a significant $p=0.004$ and a big Wald statistic $=47.003$ with a positive direction of $\beta=1.509$. The findings imply that financial capital contributes positively to employment among secondary school graduates in Kigoma District.

Furthermore, FGDs revealed various sources of loans and their accessibility challenges. The loan sources include banks such as NMB and CRDB, small lenders such as FAIDIKA, TUNAKOPESHA, and BARICK. Another source of soft loans from Kigoma Municipality and Kigoma District Council Women, Youth, and People with disability Fund. The District Council fund is organised from a 10\% of Council's internal revenues with allocations of $40 \%$ for Women Development Fund (WDF), 40\% for Youth Development Fund (YDP), and 20\%for people with disability. The consensus among participants was that "sources of capital are difficult because they mostly need collaterals, which many young secondary school graduates do not have." (13 $3^{\text {th }}$ June 2019 at SIDO Kigoma Municipality). According to the discussions, there were no clearer procedures for accessing loans from the Municipal and District Councils". In this respect, some respondents believed that credit access criteria were based on political affiliations. Due to that belief, some loan defaulters were not followed or harassed because they belonged to the ruling political party. These respondents' claims are in line with findings by National Audit Report of 2014 cited in Poncian (2015) which showed that 58 Local Govern Authorities did not recover WDF and YDF amounting Tanzania shillings 1,389,192,866.

The FGD findings were consistent with findings from Key Informants from the community development office who oversaw the fund/loan distribution who revealed that the biggest challenge was having many people in need but little money for disbursement. The KI commented as follows:

"... the 10\% fund from council own sources are too small to meet the needs because some sources which were used to generate own sources of revenue have been directed to the central Government..." (KI, Community Development officer, Kigoma on $6^{\text {th }}$ June 2019).

The KI finding shows that the District Council financial capital needs in terms of loans and grants are bigger than the availability of funds. Informal enterprise as shown in Table 2 and require financial support to improve productivity, expansion and creation of more employments. The finding indicates necessity for District councils and other stake holders to review and increase funds to support as many as possible applicants.

On the management of the fund and procedure of identifying people in need of loan, the KI cited challenges on repayment and mechanisms of tracking down defaulters for fear that people might hate the government. The findings on accessibility and benefits from WDF and YDF in Kigoma District were slightly in contrast to the findings in a study by Mtenga (2018) who observed prevalence of impartiality and benefits to lenders of WDF and YDF in Dodoma Municipality. Similar observations were made in a study by Ikasu (2019) in Mbulu District. Nevertheless, the Finance Act 2018 (URT, 2018) stipulate clearly on the 10 percent revenues for non-interest loans and the regulations if well managed, WDF, YDF and people with disability fund can assist those who really need start-ups in the informal sector through provision of funds.

Table 4: Impact of informal labour market conditions and transferrable competences on secondary school graduates' informal employment choices

\begin{tabular}{lrrrrrr}
\hline Explanatory variables & \multicolumn{1}{c}{ B } & \multicolumn{1}{l}{ S.E. } & \multicolumn{1}{c}{ Wald } & df & Sig. & Exp(B) \\
\hline Informal Labour Market Accessibility & 2.405 & 0.090 & 161.757 & 1 & 0.000 & 4.667 \\
Informal Labour Work Quality & 0.204 & 0.302 & 0.454 & 1 & 0.500 & 0.816 \\
Financial Capital & 1.509 & 0.058 & 47.003 & 1 & 0.004 & 3.991 \\
Social networks & 1.812 & 0.080 & 91.348 & 1 & 0.000 & 2.119 \\
labour market legal framework & -1.872 & 0.107 & 24.140 & 1 & 0.003 & 1.903 \\
Perceived employability & 0.346 & 0.103 & 14.957 & 1 & 0.001 & 1.157 \\
Age & 0.437 & 0.051 & 73.789 & 1 & 0.000 & 1.548 \\
Division(1) & 0.364 & 0.041 & 54.232 & 1 & 0.003 & 1.478 \\
Sex(1) & 0.240 & 0.313 & 0.589 & 1 & 0.043 & 1.272 \\
Marital(1) & 0.028 & 0.323 & 0.008 & 1 & 0.931 & 0.972 \\
Constant & -1.606 & 1.217 & 0.248 & 1 & 0.619 & 0.546 \\
\hline
\end{tabular}

Model fitting information: Omnibus test Chi-square $=142.960(\mathrm{p}=0.000)$, Hosmer and Lemeshow test $=0.762$ $\left(\mathrm{p}=0.762,-2 \log\right.$ likelihood 271.50 , Cox and Snell $\mathrm{R}^{2}=0.398$, Nagelkerke $\mathrm{R}^{2}=0.645$

Another notable variable with strong influence on employment was social networks. It showed a significant 
$\mathrm{p}=0.000$ and a Wald statistic $=31.348$ with a positive direction of $\beta=1.812$. The findings show that social networks contributed positively to employment among secondary school graduates in Kigoma District. The findings are consistent with the findings from a Key Informant who commented thus: “... many of the palm oil processing units are artisan and family owned with majority of the workforce coming from the same family relatedness..."(KI SIDO Kigoma on $7^{\text {th }}$ June 2019).

The KI finding shows two things; one is the social network contribution in accessing informal employment and secondly rises implications for those without networks with employers. There is a need for actors like community development offices to support information exchange between employers and employment seekers especially those without connection. In addition, with growth of technology, social networks include digital social platforms; digital informal employment search engines, personal history acquaintances such as classmates and schoolmates.

Similarly, these results are consistent with findings of a study by Muhanga (2017) who showed that majority of informal enterprises were family owned and significantly comprised family members as a source of labour. Informal labour market accessibility indicated a strong positive influence on employment. In addition, a study by Ada (2017) showed a significant relationship between social media and pre-employment. Overall, the findings indicated that an increase in social networks improved the likelihood for informal employment acquisition.

Likewise, empirical findings indicated that interpersonal relation competence had significant influence on employment in the informal labour market. The findings showed a Wald statistic of $26.050(p=0.004)$ and a positive coefficient of $\beta=1.453$ indicating that secondary school graduates with strong interpersonal relation skills had a better chance of being employed in the informal labour market. The Mann Whitney U test showed that urban secondary school ranked higher in interpersonal relation skills, which is an indication that, though the regression showed that interpersonal relation skills influenced getting employment; urban respondents had better chances of benefiting more from it. A combination of these results highlights differences between urban and rural respondents in terms of transferrable competences and suggests areas for intervention if at all there could be a need of improving rural informal labour market.

Furthermore, the results in Table 4 show that labour market legal framework had strong negative influence of (Wald statistic $=91.348 ; p=0.003$ and a coefficient of -1.872) indicating that an increase in labour market legal framework affected employment negatively. The results show that the growth of employment in the informal labour markets was at odds with an increase of legal compliances, as the opposite was the case. These findings were supported by the findings from two Key Informants who showed a similar concern on overregulation in the informal labour markets. On labour markets legal frameworks, one Key Informants (KI) had this to say:

"As small scale investors with small capital only to serve production and minimum salaries for workers... over regulation of social security contributions, income taxes, licences, intuitional fees like NEMC, OSHA, and many more... it is difficult to employ many employment seekers..."(KI SIDO on $7^{\text {th }}$ June, 2019).

The KI informant finding shows a distaste of cumbersome regulations and compliances employers face in dealing with fees, taxes and contribution for employs. While there are unemployed secondary school graduates and others, employers hesitate to take them because each employee comes with a list payment to the Government in terms of taxes, fees for authorities like OSHA mandatory contributions like NSSF. The advice from this finding is the government to relook on these cumbersome contributions and possibly lower them to allow for amicable mutual win-win situations between employers and employees.

Another Key Informant had this to say:

"When it comes to linking secondary education graduates with employment sector, whether formal or informal, labour laws need to support it by reducing cumbersome processes, especially for fresh informal employment seekers so that they can build experience” (TWAWEZA Official, 10 ${ }^{\text {th }}$ July 2019).

The findings suggest that labour legal frameworks must be relooked into. Such frameworks are supposed to provide security for employees and employers, and they should not be stumbling blocks to employments. At some points, employers and employees join hands together in confronting labour laws and regulations intended to serve both, formal and informal sector altogether.

A key informant (KI) from Tanzania Employers Association highlighted employment legal compliance requirement as hindrances for business registration and formalization. She said:

"Before even you start making some profit, the government requires a lot offees, taxes and contributions. For instance, apart from licenses, registration cost and quarterly taxes for the businesses, you have to pay contribution to NSSF, SDL, OSHA, NEMC, Fire, and pay some tips to local politician representatives to gain their support” (Employers Association Officer, 10 ${ }^{\text {th }}$ July 2019).

The remarks from the KI informant show challenges start-up and entrepreneurs face when they establish business. A chain of demands on registrations may shade and discourage many with a will to start but also a possible window for corruptions. The finding suggest review of these processes to encourage start-ups and enterprise formation. These hindrances can be resolved with a focus on the neoliberalism approach whereby overregulation and compliances should be discouraged to encourage start-ups and in turn increase employments, 
both formal and informal especially for unskilled secondary education graduates.

The findings are in line with the findings of a study by Ackson (2010) which says:

"Workers in the informal sector are reluctant to allow the employer to deduct monies for contributions to the social security scheme, as they would receive lower pay. Thus, employees would rather keep their already low salaries than making contributions to social security funds (Ackson, 2010).

The findings stipulate clearly that any increase in regulations is against neoliberalism theory and associated values and is likely going to lower employment opportunities, as they would likely create a burden to the employer. As result diminish the chances for employment of secondary school graduates to secure informal employments in the informal labour markets. The findings concur with conclusions by Stokes (2017) which indicated that Tanzania's heavy regulations and multiple taxations are a hindrances to firms' growth with the potential of providing employments.

The empirical findings have shown that expanding informal labour market accessibility, financial capital especially for start-ups, social networking and adjustments for labour regulation have influence on increasing informal employments. The indicated variables with influence can assist the Government and other actors to improve informal employment chances and rejuvenate economic developments. Therefore, with a focus on neoliberalism approaches, unemployment can be reduced through improving the informal labour market conditions.

\subsection{Impact of Transferrable Competences on Secondary School Graduates' Employment Status}

Binary logistic regression was computed to determine effect of transferable competences on employment status. The model summary showed an R Square of 0.432 , suggesting that the model explained $43.2 \%$ of the variations in the outcome variable as explained in the specified explanatory variables. The results of regression analysis are displayed in Table 5 and show that 4 out of the 5 transferrable competences were significant.

On the other hand, the results in Table 5 show that transferable competences; interpersonal relation and farming had influence on employment. For instance, entrepreneurship with a (Wald statistic $=12.814 ; \mathrm{p} \leq 0.001$ and a positive coefficient of $\beta=1.253$ ) indicating that an increase in entrepreneurship competences leads to an increase in employment chances in the informal labour market. Once again, these findings suggest that entrepreneurship competences for secondary school graduates are important in reducing unemployment. Similar findings are reported in a study by Haj (2015) who showed that improvements of education and skills were among the important strategies of reducing impediments to employments among the youths in Tanzania.

Table 5: Impact of informal labour market conditions and transferrable competences on secondary school graduates' informal employment choices

\begin{tabular}{lcrrrrr}
\hline Explanatory variables & B & \multicolumn{1}{l}{ S.E. } & \multicolumn{1}{c}{ Wald } & df & Sig. & Exp(B) \\
\hline Perceived employability & 0.241 & 0.134 & 11.634 & 1 & 0.041 & 1.261 \\
Self-Efficacy & 1.121 & 0.100 & 22.316 & 1 & 0.020 & 2.129 \\
Metacognition & 0.086 & 0.059 & 0.256 & 1 & 0.468 & 0.752 \\
Interpersonal Relation & 1.453 & 0.104 & 26.050 & 1 & 0.004 & 2.398 \\
Entrepreneurship & 1.253 & 0.101 & 12.814 & 1 & 0.000 & 1.288 \\
Farming competences & 2.210 & 0.082 & 29.278 & 1 & 0.001 & 1.811 \\
Age & 0.437 & 0.051 & 73.789 & 1 & 0.000 & 1.548 \\
Division(1) & 0.364 & 0.041 & 54.232 & 1 & 0.003 & 1.478 \\
Sex(1) & 0.240 & 0.313 & 0.589 & 1 & 0.043 & 1.272 \\
Marital(1) & 0.028 & 0.323 & 0.008 & 1 & 0.931 & 0.972 \\
Constant & -1.606 & 1.217 & 0.248 & 1 & 0.619 & 0.546 \\
\hline
\end{tabular}

Model fitting information: Omnibus test Chi-square $=84.720(\mathrm{p}=0.000)$, Hosmer and Lemeshow test $=0.724(\mathrm{p}$ $=0.691,-2 \log$ likelihood $198.48^{\mathrm{a}}$, Cox and Snell $\mathrm{R}^{2}=0.278$, Nagelkerke $\mathrm{R}^{2}=0.432$

The empirical findings have shown that self-efficacy, interpersonal competences, entrepreneurship, farming and have shown to have impact on informal employment acquisition. Therefore, human capital theory interventions can be sought in improving the competences for secondary school graduates.

\subsection{Conclusion}

Informal employments are important to the majority of participants in the labour force despite being considered as precarious. The study has indicated the necessity of informal employments and has explicitly shown the informal employment for urban and rural areas. The informal employment choices inform on where secondary school graduates go after completion of their studies based on places of residence. The results unveiled working places in the informal labour market for this particular group. Therefore, any strategy or intervention aimed at improving their informal employment ought to consider the differences.

In addition, differences of informal labour market conditions and transferrable competences between urban 
and rural secondary school graduates show the manner in which these aspects vary based on the respondent's location. Informal labour market conditions and transferable competences among urban and rural respondents show divergence of the ways they are influenced. The majority of informal labour market conditions have shown to be in favour of urban respondents. The findings are useful as they affirm the neoliberalism theoretical base that there are spontaneity differences in the way individuals undertake labour market conditions around them and kind of competences they find necessary for them to survive. It therefore insisted that the perceiving subject should be the measure of the way labour market conditions should be adjusted to improve their informal employment in itself and as a way toward formalization if at all is involuntary. At the same time differences shows variations in terms competences needed between rural and urban respondents.

The empirical findings have shown that expanding informal labour market accessibility, financial capital especially for start-ups, social networking and adjustments for labour regulation have influence on increasing informal employments. Also interpersonal competences, interpersonal relation, entrepreneurship and farming and have shown to have impact on informal employment acquisition. The indicated variables with influence can assist the Government and other actors to improve informal employment chances and rejuvenate economic developments Therefore, with a focus on neoliberalism approaches, interventions can be sought in improving the informal labour market and necessary transferable competences. Improvements of the two aspects are a key to serving majority of workforce in accessing employments in Tanzania.

\subsection{Recommendations}

Basing on the findings and the analysis, the following recommendations are put forward. District Councils and all other stakeholders dealing with employments should now focus on the identified informal labour market conditions for improvements. Also training institutions and other stake holders such as SIDO to provide appropriate trainings, initiate internships and assist information networking for secondary school graduates and other youths seeking employments in their areas.

Secondly, urban-rural disparity of measures should be considered when interventions are sought by government and local government authorities. The findings and the theory have shown that not one intervention fits all informal employment challenges for urban and rural respondents. District Councils and other stakeholders like loan agencies should understand and treat differently needs for urban and rural informal employments.

Lastly, District councils, Tanzania Revenue Authority, nongovernmental organisations and other labour laws enforcement agencies should cultivate friendly and mutual understanding between employers, employees, and legal entities. This would boost employment creation especially for unskilled secondary school graduate without much fear of stringent regulations.

Acknowledgement: the corresponding author acknowledge the contribution of authors for supervising, reading and correcting this paper.

Declaration of interest: there were no conflict of interest

\section{References}

Ackson T. (2010). Social Protection for the informal sector in Tanzania. [Retrieved from http://sapen.org]. site visited on $24 / 6 / 2020$.

Ada, S. (2017). an Empirical Investigation on the Use of Social Media in Human Resources Employment Process. International Journal of Disciplines In Economics and Administrative Sciences Studies 3(6):427-436.

Adams, A. et al. (2013). Improving Skills Development in the Informal Sector. Strategies for Sub-Saharan Africa. World bank, Washington. 295pp

Akhter, S. (2012). Self-efficacy and optimism as predictors of organizational commitment among bank employees. International Journal of Research Studies in Psychology 2(2): 33-42.

Assan, J., and Nalutaaya, V. (2018). Africa's Youth Unemployment Challenge and the Pursuit of Soft Skills Development by University Students. Review of European Studies 10(3): 58. https://doi.org/10.5539/res.v10n3

Amphune, B. (2012). Urban Livelihoods of Rural to Urban Migrants: A Case Study of Wolaita Sodo Town.2nd National Workshop of Research and Community Services, Wolaita Sodo University Proceeding. No. 2: (December), 0-21.

Berntson, E. and Sverke, M. (2016). Predicting perceived employability: human capital or labour market opportunities? Economic and Industrial Democracy 27(2): 223-244.

Chaudhuri, S. (2017) 'Rural - Urban Migration, the Informal Sector, Urban Unemployment, and Development Policies': (October). doi: 10.2139/ssrn.298502

Chen, M. (2012). The Informal Economy: Definitions, Theories and Policies. Journal of Entomological Science 32(1): $72-78$

DTDA. (2018). Tanzania Labour market profile. Danish Trade Union Development Agency. [Retrived from http://www.ulandssekretariatet.dk]. Site visited on 13th November, 2020. 42pp 
Ellis, M. et al. (2017) Employment and productivity growth in Tanzania's service sector. WIDER Working Paper, No. 2017/16, ISBN 978-92-9256-240-3, The United Nations University World Institute for Development Economics Research (UNU-WIDER), Helsinki. 26pp

Field, A. (2009). Discovering Statistics Using SPSS. (3rd Edition). SAGE Publication Limited, London. 821pp.

Game, I. et al. (2015). Urban Agriculture. United Nations GSDR Brief[Retrieved from https://sustainabledevelopment.un.org ] site visted on 10th November. 13pp

Gupta, M. R., "Rural-Urban Migration, Informal Sector and Development Policies: A Theoretical Analysis," Journal of Development Economics 41 (1993):137-151.

Haji, M. (2015). Youth employment in Tanzania Taking stock of the evidence and knowledge gaps Youth employment in Tanzania: Taking stock of the evidence and knowledge gaps. Canada. 30pp

Hardman, M. (2014). The rise of the 'food charter': A mechanism to increase urban agriculture. Land Use Policy (2014), http://dx.doi.org/10.1016/j.landusepol. 2014.02.022

Huang, G., Xue, D., and Wang, B. (2020). Integrating Theories on Informal Economies: An Examination of Causes of Urban Informal Economies in China. [retrived from (http://creativecommons.org on 10th July 2020)

Ikasu, E. (2019). Impact of Women Development Fund in Generating Women Enterpreneurs: Evidence from Mbulu District Council. Journal of Business School 2(6): 31-39.

ILO (2019). Women and Men in the Informal Economy: A Statistical Brief Women and Men in the Informal Economy: A Statistical Brief. Genèva. 164pp

ILO. (2003). Seventeenth International Conference of Labour Statisticians. International Labour Organization. Geneva. $153 \mathrm{pp}$

ILO. (2004a). Defining and measuring informal employment. International Labour Organization. Geneva. 22pp

ILO. (2004b). Measuring the informal economy: From employment in the informal sector to informal employment. International Labour Organization Geneva. 42pp

ILO. (2013). Measuring informality. International Labour Organization. Geneva. 42pp

IMF. (2016). The Informal Economy in Sub-Saharan Africa : Size and Determinants. International Monetary Fund. Washington DC. 31pp

Israel, G. D. (1992). Determining Sample Size, University of Florida Cooperative Extension Service, Institute of Food and Agriculture Sciences, 5pp.

Kim, D., and Lee, D. (2018). Impacts of Metacognition on Innovative Behaviors: Focus on the Mediating Effects of Entrepreneurship. Journal of Open Innovation: Technology4(2):https://doi.org/10.3390/joitmc4020018

Kucera, D., and Roncolato, L. (2019). Informal employment: Two contested policy issues. International Labour Review (December 2008). https://doi.org/10.1111/j.1564-913X.2008.00039.x

Mkenda, B. K., and Aikaeli, J. (2015). Informal Construction Employment, Earnings and Activities: A Boon or Bane for Tanzania? SSRN Electronic Journal, 4, 1-23. https://doi.org/10.2139/ssrn.2706036

Mkenda, J. A. and B. K. (2014). Determinants of Informal Employment: A Case of Tanzania' s Construction Industry Jehovaness Aikaeli and Beatrice Kalinda Mkenda 1. Botswana Journal of Economics, 12(2).

Mtenga, D. V. (2018). Performance of Women Development Fund (WDF) Toward Economic Empowerment in Tanzania. GSJ 6(11): 314-328.

Muhanga, M. (2017). Informal sector in urban areas in Tanzania: some socio-demographic, economic and legal aspects. International Journal of Accounting and Economics Studies 5(2): 163 - 168.

Natarajan, R. R., Schotte, S., and Sen, K. (2020). WIDER Working Paper 2020 / 101 Transitions between informal and formal jobs in Patterns, correlates, and consequences. Helsinki. 41pp

Peters, M. A. (2019). Hayek as classical liberal public intellectual : Neoliberalism, the privatization of public discourse and the future of democracy the privatization of public discourse and the future. Educational Philosophy and Theory 0(0): 1-7. https://doi.org/10.1080/00131857.2019.1696303

Poncian, J. (2015). The Fallacy of Limited Financial Resources for Development in Tanzania : Evidence from Local Government Authorities Audit Reports. 5(2), 39-51.

Sedgwick, P. (2014). Cross sectional studies: Advantages and disadvantages. [https://doi.org/10.1136/bmj.g2276] site visited on $20 / 5 / 2020$.

Silva, S. et al. (2013). Improving Skills Development in the Informal Sector: Strategies for Sub-Saharan Africa. Directions in Development. Washington, DC: World Bank. 295pp

Stokes, M. (2017). Employment and productivity growth in Tanzania's service sector. World Institute for Development Economics Research 2017/16 (23). 1-26

Stuart, E., Samman, E., and Hunt, A. (2018). Informal is the new normal: Improving the lives of workers at risk of being left behind. (January), 35 .

Tan, E. (2014). Human Capital Theory: A Holistic Criticism. Review of Educational Research84(3): 411-445

URT. (2008). Form Four Examination Results (CSEE). National Examination Council Of Tanzania. Dar es salaam.7pp

URT. (2014). Tanzania Integrated Labour Force Survey 2014. Ministry of Finance, Dar es Salaam, Tanzania. 189pp. 
URT. (2015). Tanzania Higher Education Development Programme2010 -2015. Ministry of Education, Science and Technology.

URT. (2016). Basic Education Statistics in Tanzania. President's Office Regional Administration and Local Government, Dar es Salaam, Tanzania. 147pp.

URT. (2017a). Mpangilio wa Mikoa kwa Ubora wa Ufaulu Katika Mtihani wa Kidato Cha Nne ( CSEE ) 2017. National Examination Council Of Tanzania. Dar es salaam.

URT. (2017b). Tanzania Human Development Report 2017. Ministry of Finance, Dar es Salaam, Tanzania.

URT. (2020). Taarifa Ya Matokeo Ya Upimaji Wa Darasa La Nne, Kidato cha Pili, na Mtihani wa kidato Cha Nne ( SCEE) na Maarifa ( Qt ) Iliyofanyika Novemba 2019. Baraza la Taifa la Mitihani. Dar es salaam

Verick, S. (2017). The Impact of Globalization on the Informal Sector in Africa. Economic and Social Policy Division, United Nations Economic Commission for Africa (ECA) And Institute for the Study of Labor (IZA). Addis Ababa, Ethiopia. 26pp

WEIGO (2014) Statistics on the Informal Economy: Definitions, Regional Estimates and Challenges. Women in Informal Employments Globalising and Organising 68 (April). 1-68pp

Williams, C. C. (2013). Evaluating cross-national variations in the extent and nature of informal employment in the European Union. Industrial Relations Journal 44 (5): 479-494

Williams, C. C. (2014). Tackling employment in the informal economy: A critical evaluation of the neoliberal policy approach. Economic and Industrial Democracy https://doi.org/10.1177/0143831X14557961

Williams, C. C., and Kedir, A. (2018). Evaluating competing theories of informal sector entrepreneurship: A study of the determinants of cross-country variations in enterprises starting-up unregistered. The International Journal of Entrepreneurship and Innovationhttps://doi.org/10.1177/1465750318782766

Williams, C. C., Windebank, J., and Bank, W. (2015). Evaluating competing theories of informal employment: some lessons from a 28-nation European survey.Int. J. Business and Globalisation, 15(1): 45-62 